\title{
175 $^{\mathrm{TH}}$ ANNIVERSARY OF BOCHDALEK'S INAUGURAL DISSERTATION
}

\author{
Pavel Cecha, David Kachlik ${ }^{\mathrm{b}, \mathrm{c*}}$ \\ a Department of History of Medicine, Third Faculty of Medicine, Charles University in Prague, Ruska 87, Praha 10, 100 00, \\ Czech Republic \\ ${ }^{b}$ Department of Anatomy, Third Faculty of Medicine, Charles University in Prague, Ruska 87, Praha 10, 100 00, Czech \\ Republic \\ c Department of Medicine and Humanities, Faculty of Biomedical Engineering, Czech Technical University in Prague, nam. \\ Sitna 3105, 27201 Kladno, Czech Republic
}

Received: September 7, 2008; Accepted (with revision): November 18, 2008

Key words: Bochdalek/Biography/History of medicine

Background: In 2008, it has been 175 years since the publication of Vincenc Alexandr Bochdalek's thesis.

Results: On October 22, 1833 he defended his inaugural dissertation in the Greater Hall of Carolinum in Prague and six days later he got his degree in the Lesser Hall of Carolinum. The dissertation was called Anleitung zur praktischen Zergliederung des menschlichen Gehirnes (A guide of the practical dissection of the human brain). It consisted of an introduction (11 pages), main section (208 pages) and an appendix with 19 defended theses. They was aimed not only at anatomy, but also at various fields of medicine, e.g. atmosphere study, treatment of tetanus by usage of antiphlogistics, comparison of the effects of venesection and drainage of the ascites, blockage of the lacrimal duct etc. Bochdalek pointed out that resorption did not occur via blood veins but via lymph vessels; presented his own views of the nerve function, denied the statement that both eye chambers were lined with the Demours' membrane; warned of overestimating the results of experiments upon animals; contemplated over the indication of the Cesarean section of the dead pregnant women; appealed not to separate the lunatic asylums from hospitals and recommended to dissect brains of the dead lunatics.

Conclusions: Although some of Bochdalek's opinions mentioned in the defended theses have been unconfirmed by modern science, this only Bochdalek's monography remains to serve as a proof of one of his findings (flower basket) which later acquired an eponym.

\section{BACKGROUND}

On the occasion of the $125^{\text {th }}$ anniversary of his death and $175^{\text {th }}$ of his inaugural dissertation, it is necessary and desirable to commemorate Vincenc Alexandr Bochdalek (see Fig. 1). Although his personality belongs to the most outstanding Czech anatomists and pathologists, the biography concerning his life and work is rather poor. Twenty-five years ago, Wondrák commemorated the merits of professor of Charles-Ferdinand University in Prague and a native of the Moravia-Silesia boundary in the Časopis lékar̆u českých ${ }^{1}$.

\section{METHODS AND RESULTS}

The data sources for the article presented: the dissertation was studied in the National Library, Prague; biographical data in parish registers in the State Regional Archives, Litoměřice and in medical biographical lexicons; the terminology in special medical lexicons in the National Medical Library, Prague, and in the database Medline (the main sources are quoted in the list of references).

Vincenc Alexandr Bochdalek was born on February 11, 1801 in Skřipov, in the Moravian-Silesian region of the Czech Republic (at that time in the Austrian part of Silesia, being part of the Crown Lands of Bohemia within the Habsbourg Monarchy). His name was stated as "Vincentz Bohdalek" in the parish register'. Bochdalek himself insisted upon the Czech pronunciation of his surname and assured it by the orthographic modification to "Bochdalek", because the German pronunciation would skip -h- and the surname would sound like „bodalek" which would change the meaning of the word. "Bohdalek" is a pet form of the Czech surname "Bohdal" what means "God has given"; the surname "Bohdal" appears at the marriage certificate of Bochdalek's father ${ }^{2}$. Bochdalek studied at the grammar school in Opava from 1816 to 1820 and after the school-leaving examination in $1820^{3}$. he left for Prague. He studied philosophy at first and then medicine, from $1825^{4}$. Due to his enthusiasm in anatomy, he started to help in the dissection halls of the Department of Anatomy. He worked on preparations of the finest ramification of the nervus vagus, phrenicus, facialis and truncus sympathicus, including their anastomoses for clinical purposes ${ }^{4}$. In 1829 he carried out the first dissection of a rabid dog in Prague, together with Vincenc Julius Krombholz ${ }^{1}$. In December 1830, Bochdalek was appointed prosector at the Department of Anatomy, still as a student ${ }^{3,4}$. 


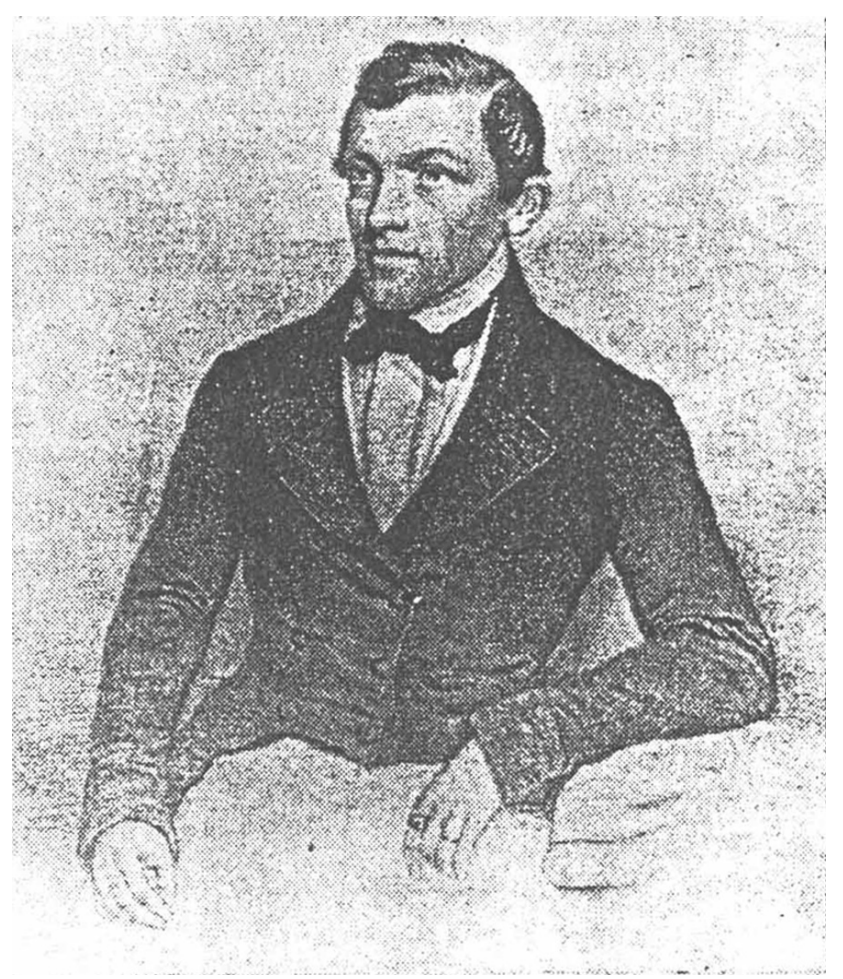

Fig. 1. Vincenc Alexandr Bochdalek.

He focused on writing and completing his inaugural dissertation Anleitung zur praktischen Zergliederung des menschlichen Gehirnes (A guide of the practical dissection of the human brain) for nearly three years (see Fig. 2). He presented the dissertation lecture including the defense of appended nineteen theses, not included in the text of dissertation proper, on October 16, 1833, at 10 a.m., in the Greater Hall of Carolinum, at the Charles-Ferdinand University in Prague and on October 22, 1833, at 11 a.m. he got his degree in the Lesser Hall of the building ${ }^{3,5}$.

The nineteen defended theses aimed not only at anatomy but also at various fields of medicine (treatment of tetanus by usage of antiphlogistics, atmosphere study, blockage of the lacrimal duct, comparison of the effects of venesection and drainage of the ascites, etc.). Among others, he stated that resorption did not occur via blood veins but via lymph vessels; presented his own views of the nerve function; denied the statement that both eye chambers were lined with the Demours membrane; warned of overestimating the results of experiments upon animals; contemplated over the indication of the Cesarean section of the dead pregnant women; drew attention to various animals and plants; appealed not to separate the lunatic asylums from hospitals; recommended to dissect brains of the dead lunatics; advised to parents and foster parents to inspect children every two weeks carefully because of possible orthopedic defect, and considered the medical popular treatises to bring more problems and misunderstanding than benefit.

The dissertation without the defended theses was published then in Prague in 1833 and was composed of the introduction (11 pages) and the main section (208

\section{A I \\ $z \mathrm{ur}$ \\ praktischen 3ergltederung \\ des \\ menschlichen Gehirnes,}

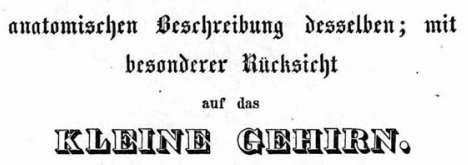

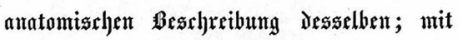
besmiderer Whitchsidljt

auf das

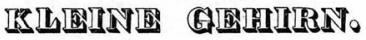

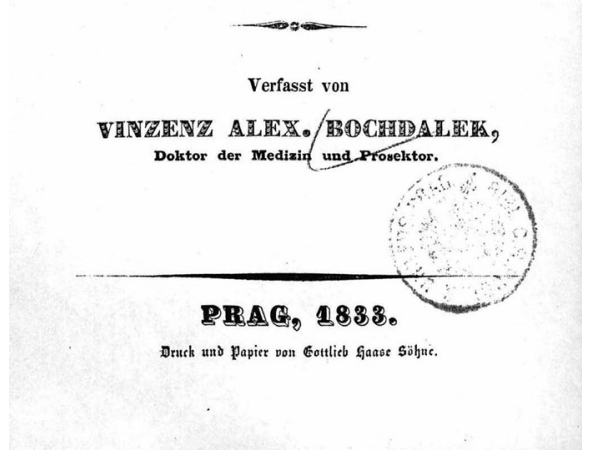

Fig. 2. Bochdalek's dissertation title page.

pages) containing the systematic description of the brain. Some of Bochdalek's opinions mentioned in the thesis has been unconfirmed by modern science. This monography of Bochdalek remains to serve as a proof of his findings ${ }^{6}$.

In 1833, Bochdalek applied for the Chair of Anatomy, but Joseph Hyrtl was chosen to head the department. Bochdalek then became the first pathological prosector ever in Prague (1837) $)^{5,7}$. In 1840 he was appointed associate professor of pathological anatomy. When Hyrtl left for Vienna, Bochdalek was appointed full professor of comparative and surgical anatomy. He was elected thrice as the dean of the Board of Professors of the Faculty of Medicine $(1861 / 62,1862 / 63,1863 / 64)$. He was a member of the Society of Czech Physicians (Spolek lékařův českých), associate member of the Royal Bohemian Society of Sciences (Královská česká společnost nauk), and member of the Society of Physicians in Vienna. In 1870 he received the order of knighthood from the Emperor Franz Joseph I. ${ }^{3,7}$.

As for his other publications, there were 27 original articles issued mostly in Vierteljahrschrift für praktische Heilkunde, Oesterreichische Zeitschrift für die praktische Heilkunde, Virchows Archiv, Reicherts und Dubois Archiv, not counting reviews and critiques. Bochdalek wrote two studies about the diaphragmatic hernias. In the Einige Betrachtungen über die Entstehung des angeborenen Zwerchfellbruches (Several observations on the rise of the inborn diaphragmatic hernia, 1848) he focused on explaining the origin of inborn diaphragmatic hernia as an arrest of diaphragm formation and described a triangle with its base at the twelfth rib. He also thought about the possibility of treatment for the posterior diaphragmatic 
hernia. He supposed that if it were possible to state the diagnosis in vivo, a surgical procedure involving a section close below the twelfth rib could be done. By pushing the left suprarenal gland and kidney caudally, a reposition of the hernia content back into the abdominal cavity would allow the lung to inflate again ${ }^{8}$. In the Praktische Bemerkungen über Zwerchfellbrüche nebst Beschreibung eines mit einer Fraktur der Lendenwirbelsäule complizierten Falles (Practical remarks on diaphragmatic hernias besides a description of a case complicated with a fracture of the lumbar spine, 1867) he presented a case of a miner who was buried with coal and suffered a fracture of the spine with a spinal cord lesion, traumatic defect of the diaphragm allowing the stomach, spleen, and a part of the small intestine to slide into the thoracic cavity resulting in the collapse of the left lung 9 .

Bochdalek retired in 1872 and left for Litoměřice in the north Bohemia, where he died on February 3, 1883 presumably of the laryngeal oedema.

During his forty-year career as an anatomist and pathologist at departments of the Prague Medical Faculty and the General Hospital in Prague, he dissected thousands of cadavers, approximately 600-800 per year and discovered numerous unknown anatomical or pathological structures in the human body and described several pathological units and observations. As a result of his devoted and strenuous work in these fields, his name has entered the world science as eponym in the medical terminology. Although he is nearly forgotten in his own country, his name is known worldwide among all medical specialists and the memory of the Czech scientist will survive for centuries.

To survey all the terms in both anatomy and pathology connected with the eponym Bochdalek, many medical dictionaries, encyclopedias, and lexicons as well as articles published in not only medical journal in years 1950-2007 and indexed in Medline were checked.

There is a list of terms used as eponyms in combination with the adjective „Bochdalek's“ or "of Bochdalek“ ranked alphabetically: canal, cleft, cyst, defect, duct, flower basket, flower spray, foramen, ganglion, gap, gland, hernia, herniation, hiatus, muscle, orifice, plexus, sinus, triangle/trigone, tube, type, valve. If a non-English equivalent was used, the term was translated to English to simplify the results. In some cases, there are homonyms present, i.e. some terms describe two different structures: canal, ganglion, muscle and plexus.

The most used terms out of 26 found are these 10 following, but describing only three structures:

Canal, cleft, defect, foramen, gap, hiatus, orifice, sinus, trigone / triangle (kanál, otvor, trojúhelník in Czech) - synonyms of the embryonal pleuroperitoneal hiatus, changing in the permanent lumbocostal triangle of the diaphragm.

Hernia, herniation (kýla in Czech) - a congenital posterolateral diaphragmatic hernia, penetrating via the above mentioned structure.

Flower basket / spray (keřiček in Czech) - part of the choroid plexus of the fourth ventricle protruding through the lateral aperture (Luschka's foramen) in the lateral cer- ebellomedullary cistern and resting on the dorsal surface of the glossopharyngeal nerve.

The terms hernia and canal/foramen/triangle of Bochdalek are very frequently used in the older and recent bibliography due to their high clinical importance especially in the neonatology and children surgery. The other eponyms can be considered as fading out and have not been recalled in both the written and oral form ${ }^{9-27}$.

\section{CONCLUSION}

Vincenc Alexandr Bochdalek was one of the best and most important Czech anatomists and pathologists in history. His fate was completely connected with the Czech region and Prague, but due to his achievements, described in his dissertation, his name and personality are more popular abroad than in his homeland. His name is forever bound with two terms - the trigonum lumbocostale diaphragmatis and the hernia in the posterior part of the diaphragm.

\section{REFERENCES}

1. Wondrák E. Český anatom a patolog V. A. Bochdalek - 100 let od smrti. Čas Lék Čes 1983; 122:1334-7.

2. Wondrák E. Vincenc Alexandr Bochdalek (1801-1883), český anatom a patolog. Acta Univ Pal Olomuc 1962; 22:137-42.

3. Biografický slovník pražské lékařské fakulty 1348-1939. Díl I. A-K. Praha: Univerzita Karlova; 1988. p. 82-3.

4. Ottův slovník naučný 4. díl. Praha: Paseka; 1997. p. 263.

5. Matoušek O. Lékaři a přírodovědci doby Purkyňovy. Praha: SPN; 1954. p. 35-9

6. Bochdalek VA. Anleitung zur praktischen Zergliederung des menschlichen Gehirnes, nebst einer anatomischen Beschreibung desselben; mit besonderer Rücksicht auf das kleine Gehirn. Prag: Gottlieb Haase Söhne; 1833.

7. Navrátil M. Almanach českých lékařủ. Praha: M. Navrátil; 1913. p. 22.

8. Bochdalek VA. Einige Betrachtungen über die Entstehung des angeborenen Zwerchfellbruches. Als Beitrag zur Anatomie der Hernien. Vierteljahrschrift prakt Heilkunde 1848; 5:89-97.

9. Bochdalek VA. Praktische Bemerkungen über Zwerchfellbrüche nebst Beschreibung eines mit einer Fraktur der Lendenwirbelsäule complizierten Falles. Vierteljahrschrift prakt Heilkunde 1967; 24:14-27.

10. Butterworths Medical Dictionary. London : Butterworths; 1965.

11. Cerilli GJ. Foramen of Bochdalek Hernia. Ann Surg 1964; 159:3859.

12. Dictionnaire de médecine Flammarion Sous la direction de Serge Kernbaum. 6e-éd. Paris: Flammarion; 1998.

13. Dobson J. Anatomic Eponyms. London: Bailliere, Tindall \& Cox; 1946.

14. Dorland's Illustrated Medical Dictionary. 26th ed. Philadelphia: W.B. Saunders Co.; 1981

15. Duden. Das Wörterbuch medizinischer Fachausdrücke 4., vollst. überarb. u. erg. Aufl. Stuttgart: Thieme; 1985.

16. Handlexikon der Medizin Hrsg. von Dr. Günther Thiele. München: Urban \& Schwarzenberg; 1980.

17. Hardy J D. Diaphragmatic Hernias. Am J Surg 1962; 103:342-51.

18. Harjola PT. Patent ductus arteriosus and Bochdalek's Hernia. J Cardiovasc Surg 1964; 5:37-40.

19. Holub E, Fargaš E, Schwarzer M. Angeborene Hernien im Bochdalekschen Dreieck und in posterolateralen Zwerchfelldefekten. Zentralblatt Chir 1961; 86:1433-47. 
20. Jäckel E. Beitrag zur Klinik der Zwerchfellhernien. Zentralblatt Chir 1964; 89:705-17.

21. Kelly EC. Encyclopedia of Medical Sources. Baltimore: Williams \& Wilkins; 1948.

22. Kostić AD. Medicinski rečnik. Beograd: Medicinska knjiga; 1956.

23. Pschyrembel Klinisches Wörterbuch. Berlin: Gruyter; 1998.

24. Stedman's Medical Dictionary 26th ed. Baltimore: Williams \& Wilkins; 1995.
25. Taber's Cyclopedic Medical Dictionary. Philadelphia: Davis Co.; 1973.

26. Zetkám M, Schaldach H. Wörterbuch der Medizin. Band 1+2. 11., überarb. Aufl. Hrsg. Von Herbert Schaldach. Berlin: VEB Verlag; 1980.

27. Enciklopedičeskij slovar medicinskich terminov. Moskva: Sov. Enciklopedija; 1982 (Энциклопедический словарь медицинских терминов Изд. Первое. Глав. Ред. Б. В. Петровский. Издат. „Сов. Энциклопедия«, Москва 1982). 